\title{
Detection and genotyping of human papillomavirus in breast cancer tissues from Iraqi patients
}

S.H.M. Ali, ${ }^{1}$ N.A.S. Al-Alwan ${ }^{2}$ and S.H.M. Al-Alwany ${ }^{1}$

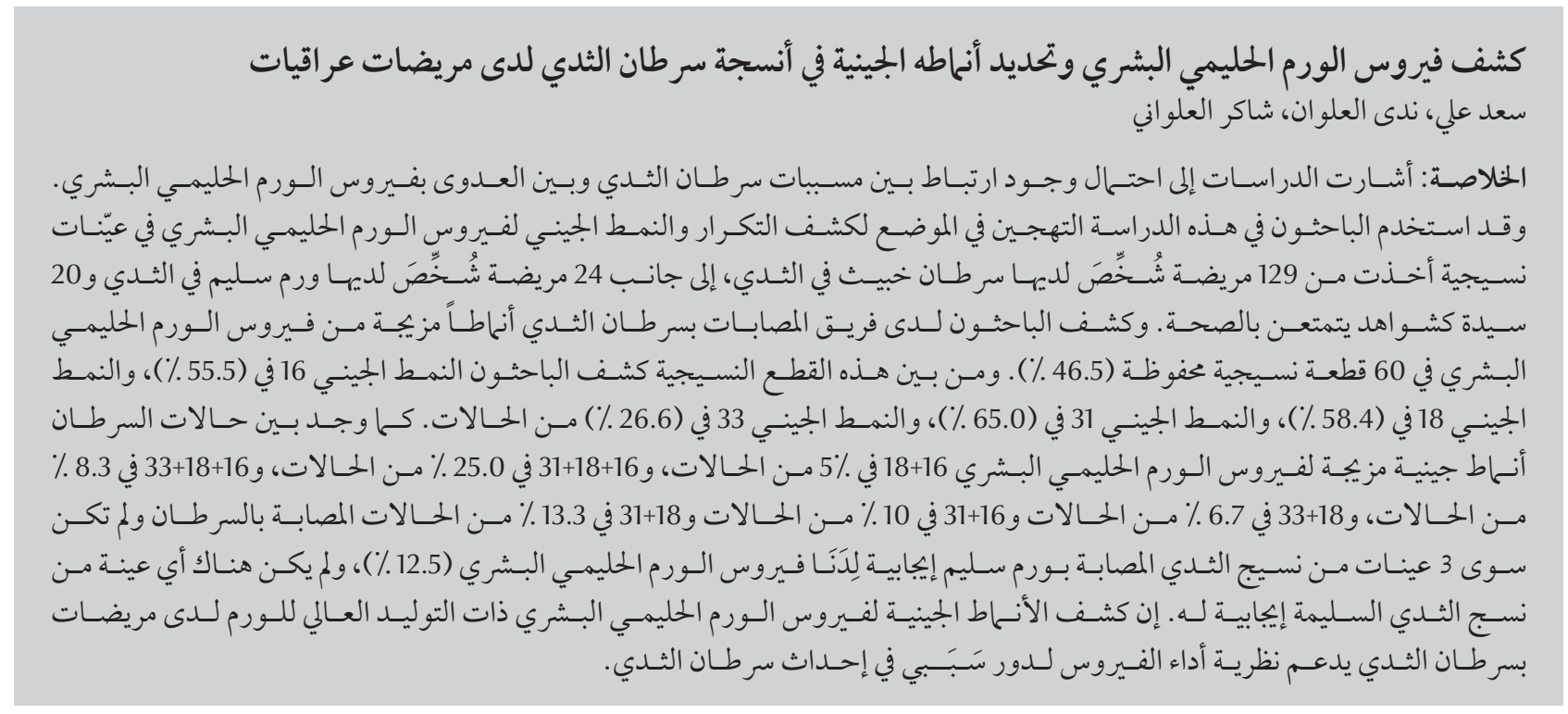

ABSTRACT Studies have suggested a possible link between breast cancer pathogenesis and human papillomavirus (HPV) infection. This study in Iraq used in situ hybridization to detect the frequency and genotyping of HPV in tissue specimens from 129 patients diagnosed with malignant breast cancer, 24 with benign breast tumours and 20 healthy controls. In the breast cancer group, cocktail HPV genotypes were detected in 60 (46.5\%) archived tissue blocks. Of these, genotypes 16 (55.5\%), 18 (58.4\%), 31 (65.0\%) and 33 (26.6\%) were detected. Mixed HPV genotypes $16+18,16+18+31,16+18+33,18+33,16+31$ and $18+31$ were found in $5.0 \%, 25.0 \%, 8.3 \%, 7.7 \%, 10.0 \%$ and $13.3 \%$ of cancer cases respectively. Only 3 benign breast tumour tissues $(12.5 \%)$ and none of the healthy breast tissue specimens were HPV-DNA-positive. The detection of high-oncogenic HPV genotypes in patients with breast cancer supports the hypothesis of an etiologic role for the virus in breast cancer development.

\section{Détection et génotypage du papillomavirus humain dans les tissus mammaires cancéreux de patientes en Iraq}

RÉSUMÉ Des études ont suggéré qu'un lien était possible entre la pathogénèse du cancer du sein et l'infection à papillomavirus humain. L'étude menée en Iraq a utilisé la méthode d'hybridation in situ pour déterminer la fréquence du papillomavirus humain et pour son génotypage dans les échantillons de tissus prélevés auprès de 129 patientes ayant reçu un diagnostic de cancer du sein malin, de 24 patientes porteuses d'une tumeur du sein bénigne et de 20 femmes témoins en bonne santé. Dans le groupe des patientes atteintes d'un cancer du sein, différents génotypes de papillomavirus humain ontété détectés dans 60 échantillons detissus conservés(46,5\%). Parmi ceux-ci, on peutciterles génotypes16 (55,5\%),18(58,4\%),31(65,0\%)et33(26,6\%).Lesassociationsdegénotypesdepapillomavirushumain16+18, $16+18+31,16+18+33,18+31,16+31$ et $18+33$ ont été observées chez 5,0\%,25,0\%, 8,3\%, 6,7\%, 10,0\% et 13,3\% des cas de cancer respectivement. Seuls trois échantillons de tissu mammaire tumoral bénin (12,5\%) étaient positifs pour I'ADN de papillomavirus humain tandis qu'aucun échantillon de tissu mammaire sain ne l'était. La détection de génotypes du papillomavirus humain hautement oncogènes chez les patientes atteintes de cancer du sein vient appuyer l'hypothèse du rôle étiologique du virus dans l'apparition d'un cancer du sein.

${ }^{7}$ Communicable Disease Research Unit, Baghdad Medical College, Baghdad, Iraq.

2Iraqi National Cancer Research Centre, Baghdad of University, Baghdad, Iraq (Correspondence to N.A.S. Al-Alwan: nadalwan@yahoo.com). Received: 24/12/12; accepted: 26/08/13 


\section{Introduction}

Breast carcinoma is the commonest malignancy among women in developed and developing countries including Iraq $(1,2)$. Local studies in Iraq have demonstrated that most breast cancer patients present in advanced stages with a likely prevalence of more aggressive tumour forms $(3,4)$. Many risk factors have been associated with breast cancer development and progression including a possible viral etiology (5). Previous studies have demonstrated the presence of high-risk human papillomavirus (HPV) genotypes 16, 18 and 33 in breast cancer specimens from diverse populations around the world (6-8). Nevertheless, a definitive relationship between human breast cancer and HPV infection has not yet been determined (9). There is a need to obtain additional evidence in order to assess the possibility of breast cancer prevention using HPV vaccines.

High-risk HPV encodes a series of proteins, some of which have oncogenic potential (10). The biology of HPV in breast cancer is almost identical to that in cervical cancer, although a significantly higher viral load is evident in the latter (10). It has been observed that the presence of HPV in breast cancer was associated with the detectable expression of the HPV E6 oncogenic protein and the p16(INKa4) protein, which is an indicator of E7-mediated inactivation of the p110(Rb) protein (11). The present study represents the first of its kind in Iraq to explore a possible etiological association between high oncogenic-risk HPV types and breast cancer.

\section{Methods}

\section{Tissue samples}

This retrospective study used 173 selected formalin-fixed, paraffin-embedded blocks from breast tissue samples from
129 patients with breast carcinomas (100 cases of ductal mammary carcinoma not otherwise specified, 17 cases of lobular carcinoma, 5 cases of mixed ductal and lobular carcinoma and 7 cases of medullary carcinoma) and 24 patients with benign epithelial mammary lesions. A further 20 blocks from samples from normal breast tissues were labelled as a control group (i.e. normal healthy breast tissues). The age range of the patients was $16-72$ years. The specimens were collected during the period 2008-11 from major hospitals and private laboratories in the mid-Euphrates governorates of Iraq including Babylon, Kerrbla, AlNajaf, Al-Qadiyisia and Al-Muthana. The diagnoses were based on the recorded pathological reports of the corresponding patients.

\section{Laboratory methods}

Thick-tissue sections (4 mm) were prepared and stuck onto positively charged slides. An in situ hybridization (ISH) detection system (Zytovision $\mathrm{GmbH}$ ) was used to target DNA sequences in tissue specimens using digoxigenin-labelled cocktail HPVDNA probes for a wide range of high-risk HPV genotypes including genotypes 16, 18, 31, 33, 35, 45, 51 and 82 . The ISH signals were detected as red discolouration at the site of sequence complementarity as nuclear signals by proper use of the Zytovision system.

Another ISH detection system (Maxim Biotech Inc.) was used to target DNA sequences using a biotinylated long DNA probe for HPV genotypes 16, 18, 31 and 33 in tissue specimens. The methods were conducted according to the instructions of the manufacturing company. Positive reactions were performed by replacing the probe with a biotinylated housekeeping gene probe. For the negative control, all reagents were added except the diluted probe. Proper use of this ISH detection system gives an intense blue signal at specific sites of the hybridization probe in positive test tissues (according to the specification of the second differential kit which gave the blue colour). The signal was evaluated under light microscopy using $x$ 100 lens for counting the positive cells. The ISH results were given percentage scores based on positive signals and number of cells that gave these signals.

\section{Analysis}

Positive cells were counted in 10 different fields of 100 cells for each sample and the average percentage of positive cells within the 10 fields was determined. Cases were assigned to one of the following percentage score categories: $1 \%-25 \%$ (score 1), $26 \%-50 \%$ (score 2 ) or $>50 \%$ (score 3) (12). The chi-squared test was used to detect the significance between groups. The statistical analysis was done using SPSS program, version 17 , and differences were considered significant when $P<0.05$ (13).

\section{Results}

\section{Detection and genotyping of HPV}

Table 1 shows the positive results of the HPV-DNA ISH detection; 60/129 breast cancer cases (46.5\%; 95\% CI: $37.9 \%-55.1 \%)$ revealed positive red signals. In the benign tumour group 3/24 (12.5\%) revealed positive red signals. None of the healthy breast tissues presented positive signals for the HPV ISH test. Of the positive cases, 31/60 (51.7\%) breast cancer tissues had score 3 ( $>50 \%$ positive cells), while $2 / 24$ (66.7\%) benign tumour tissues had score 3 .

The microscopic appearance of generic HPV-positive ISH red signals in breast cancer and healthy tissues are illustrated in Figure 1. The signals of ISH for genotyping HPV were detected as blue nuclear signals at the sites of sequence-complementarities (Table 


\begin{tabular}{|c|c|c|c|c|c|c|}
\hline \multirow[t]{2}{*}{ HPV signal scoring } & \multicolumn{2}{|c|}{ Malignant breast tumour group } & \multicolumn{2}{|c|}{ Benign breast tumour group } & \multicolumn{2}{|c|}{ Healthy breast group } \\
\hline & No. & $\%$ & No. & $\%$ & No. & $\%$ \\
\hline \multicolumn{7}{|l|}{ Signal } \\
\hline Negative & 69 & 53.5 & 21 & 87.5 & 20 & 100.0 \\
\hline Positive $^{a}$ & 60 & 46.5 & 3 & 12.5 & 0 & 0.0 \\
\hline Total & 129 & 100.0 & 24 & 100.0 & 20 & 100.0 \\
\hline \multicolumn{7}{|l|}{ Scores $^{b}$} \\
\hline 1 & $9 / 60$ & 15.0 & $0 / 3$ & 0.0 & $0 / 0$ & 0.0 \\
\hline 2 & $20 / 60$ & 33.3 & $1 / 3$ & 33.3 & $0 / 0$ & 0.0 \\
\hline 3 & $31 / 60$ & 51.7 & $2 / 3$ & 66.7 & $0 / 0$ & 0.0 \\
\hline Mean rank & & 95.6 & & 67.1 & & 55.5 \\
\hline
\end{tabular}

${ }^{a}$ Mann-Whitney test for difference in mean rank comparing: all 3 study groups $(P<0.001)$; benign tumour versus healthy groups ( $\left.P=0.11\right) ;$ malignant tumour versus healthy groups $(P<0.001)$; malignant versus benign tumour groups $(P=0.004)$. Kruskal-Wallis test for difference in signal scoring comparing: malignant versus benign tumour groups for $\mathrm{HPV}$-positive cases $(P=0.52)$. Healthy controls were not compared because all were HPV negative.

${ }^{b}$ Score 1: 1\%-25\%; score 2: $26 \%-50 \%$; score 3: > 50\%.

IIndicates significant differences in rates of positivity of HPV detection compared with ranks of HPV detection rates in the groups showing benign tumours and healthy breast tissues.

2 and Figure 2). Table 2 shows that in breast cancer cases the frequency of HPV genotype 33 (12.4\%) was significantly lower than genotype 31 , which was the most frequent genotype (30.2\%). The distribution of HPVDNA genotypes in the malignant tumour group were as follows: HPV 16 (25.6\%), HPV 18 (27.1\%), HPV 31 (30.2\%) and HPV 33 (12.4\%). These results demonstrate that $\mathrm{HPV}$ genotype 31 occurred at a higher rate than other genotypes. The total positive cases in the table refer to positive cases that may have more than one genotype of HPV.

Tables 3 and 4 show the rates of co-infection with multiple HPV

A

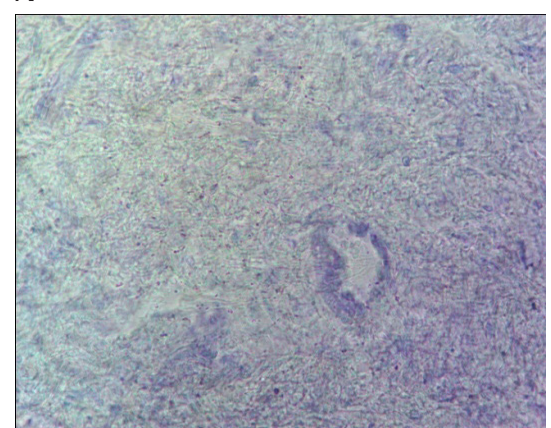

genotypes in patients with benign and malignant breast tumours. Among the 60 samples in the malignant group positive for HPV, the highest percentage of co-infection with multiple high-risk of HPV genotypes $16+18+$ 31 was found in $15(25.0 \%)$ cases. Coinfection with other high-risk HPV genotypes in the malignanat group were as follows: HPV $16+18$ (5.0\%), HPV $16+18+33$ (8.3\%), HPV $18+$ $33(6.7 \%)$, HPV $16+31(10.0 \%)$ and HPV $18+31$ (13.3\%). Positive signals indicating high-risk HPV infection were found in $3 / 24(12.5 \%)$ benign breast tumour tissues, among which 1 case showed mixed HPV infection

B

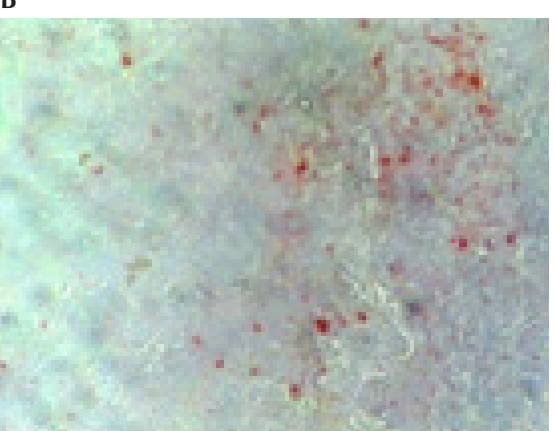

Figure 1 Microscopic appearance of generic HPV-positive in situ hybridization red signals in epithelial breast tissues. $A$ = malignant tumour (HPV positive); $B$ = healthy breast (HPV negative) with HPV types $18+31(33.3 \%)$. A significant difference in the rates of coinfection by high-risk HPV genotypes was observed between the benign and malignant breast tissue groups $(P<$ $0.05)$.

\section{Discussion}

The majority of molecular events in the genesis of breast cancer are unknown. However, initial studies have reported an association of breast cancers with cervical intraepithelial neoplasia-III-like lesions (14).

High oncogenic-risk HPV genotypes such as HPV 16, 18, 31 and 33 were detected in cases of breast cancer in this study. Despite great variability in the HPV detection rates worldwide, the majority of HPV types detected are of the high oncogenic-risk group (HPV genotypes $16+18$ ) (15). It has been reported that the association of high oncogenic-risk HPV types is stronger in invasive breast carcinomas, indicating a possible relationship with the pathology and grade of the disease (16).

The transmission route of HPV detected in breast cancer is unclear. 


\begin{tabular}{|c|c|c|c|}
\hline \multirow[t]{2}{*}{ Genotype } & \multicolumn{3}{|c|}{$\begin{array}{l}\text { Malignant tumour group } \\
\qquad(n=129)\end{array}$} \\
\hline & No. & $\%^{\mathrm{a}}$ & $95 \% \mathrm{Cl}$ \\
\hline 31 & 39 & 30.2 & $22.3-38.1$ \\
\hline 18 & 35 & 27.1 & $19.4-34.8$ \\
\hline 16 & 33 & 25.6 & 18.1-33.1 \\
\hline 33 & 16 & 12.4 & 6.7-18.1 \\
\hline
\end{tabular}

${ }^{a}$ Friedman test comparing genotypes $(P<0.001)$. $C l=$ confidence interval for prevalence.

Two independent studies suggested a possible haematogenic and/or lymphatic transfer of the virus from one organ to another (17). Investigators revealed the presence of HPV in

nipple secretions, suggesting that HPV may transfer in a retrograde fashion from the nipple via the areola, lactiferous ducts and sinuses (18). In the present study, generic/cocktail high
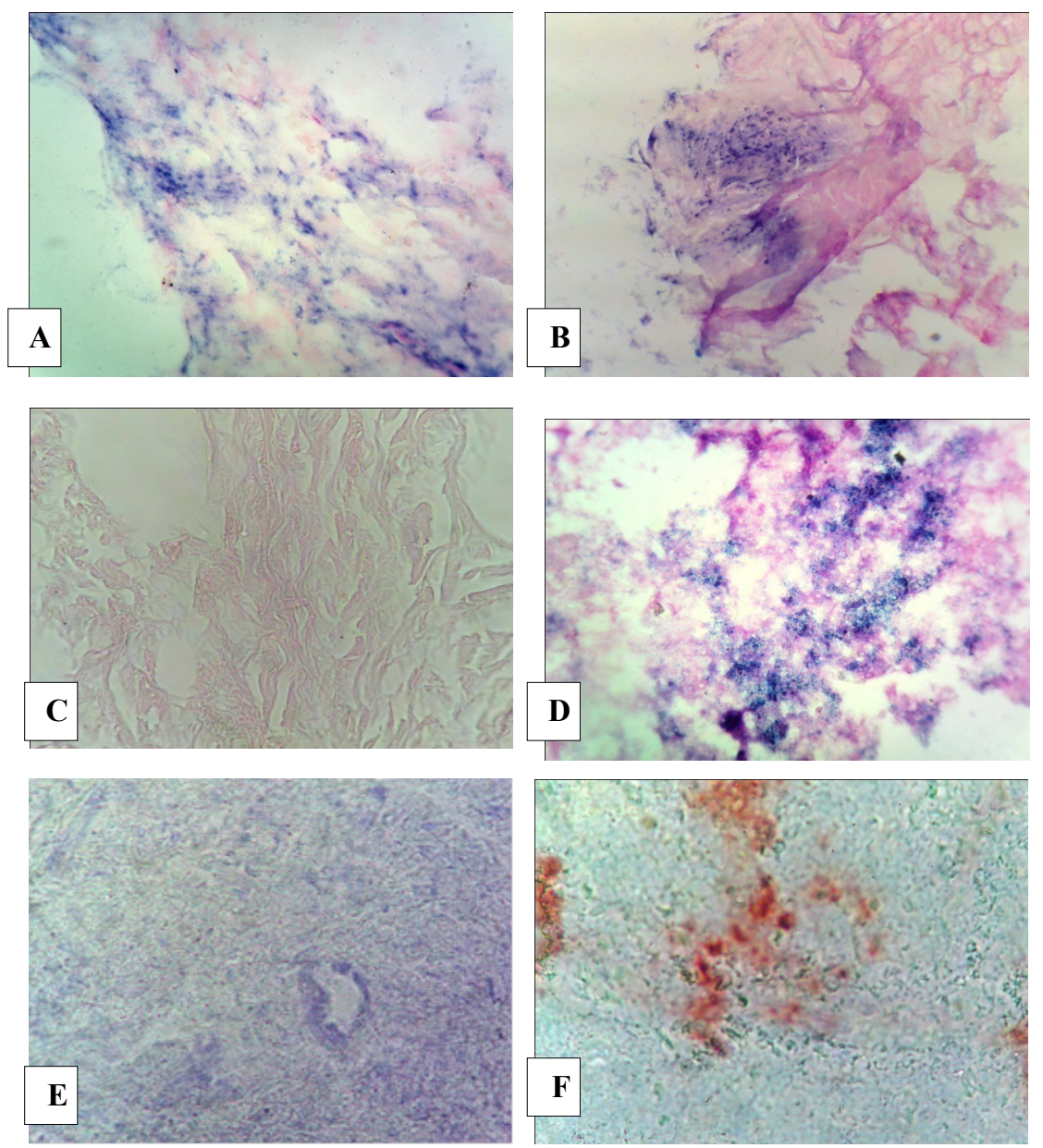

Figure 2 Microscopic appearance of human papillomavirus (HPV)-positive in situ hybridization signals of epithelial breast tumour. $A=$ malignant tumour (HPV 16 positive); $B$ = malignant tumour (HPV 18 positive); $C=$ malignant tumour (HPV 31 positive); $D=$ healthy breast (HPV negative); $E=$ malignant tumour (HPV 33 positive); $\mathrm{F}=$ healthy breast (HPV negative) oncogenic-risk types were detected in $46.5 \%$ of cases. The reported prevalence of HPV infection in breast cancer tissues shows a great variation worldwide, ranging from $0 \%$ to $86 \%(19,20)$. Demographic features and genetic background might contribute to the global geographical differences of HPV prevalence in breast carcinoma tissues. Nevertheless, other reasons for the different results reported in the literature may be attributable to the variation in the numbers of tested samples and sensitivity of the technical methods used in evaluation including the primer sets (21).

It has been reported that virions are shed from desquamating keratinocytes (the target cells from HPV infections) and high-risk HPVs can be transmitted by close human non-sexual contact (22). Accordingly, we speculate that HPVs may be transmitted by hand from the female perineum to the breast which might occur during showering or bathing. It has been well documented as well that hormonal factors (oestrogen and its derivatives) are known to be involved in breast carcinogenesis (23) and that oestrogen receptor-positive breast carcinomas are more sensitive to tamoxifen. The presence of oestrogen or progesterone receptors was not related to HPV detection in breast carcinomas (24).

The origin of breast cancer remains multifactorial. If $\mathrm{HPV}$ is considered to play an etiological role in breast cancer development, as in cervical carcinogenesis, it would be reasonable to expect that it would be possible to detect the virus at an early stage of the disease, and that HPV would be found at least in some normal tissues (9). The fact that we did not find viral DNA in healthy breast specimens could support, to a certain extent, the hypothesis that the virus might play a role in the etiology of breast cancer in only a subpopulation of patients. On the other hand, it is logical to believe 


\begin{tabular}{|c|c|c|c|c|}
\hline \multirow[t]{2}{*}{ Genotypes } & \multicolumn{2}{|c|}{$\begin{array}{l}\text { Malignant breast tumour group } \\
\qquad(n=60)\end{array}$} & \multicolumn{2}{|c|}{$\begin{array}{l}\text { Benign breast tumour group } \\
\qquad(n=3)\end{array}$} \\
\hline & No. & $\%$ & No. & $\%$ \\
\hline Single genotype & 17 & 28.3 & 2 & 66.7 \\
\hline Combined (multi) genotypes & 43 & 71.7 & 1 & $33.3^{\mathrm{a}}$ \\
\hline
\end{tabular}

${ }^{a}$ KruskalWallis test comparing benign and malignant cancer groups for the presence of co-infection by high-risk HPV genotypes (P < 0.05).

\begin{tabular}{|c|c|c|c|c|}
\hline \multirow[t]{2}{*}{ Genotypes } & \multicolumn{2}{|c|}{$\begin{array}{l}\text { Malignant breast tumour group } \\
\qquad(n=43)\end{array}$} & \multicolumn{2}{|c|}{$\begin{array}{l}\text { Benign breast tumour group } \\
\qquad(n=1)\end{array}$} \\
\hline & No. & $\%$ & No. & $\%$ \\
\hline $16+18$ & 3 & 7.0 & 0 & 0.0 \\
\hline $16+31$ & 6 & 14.0 & 0 & 0.0 \\
\hline $16+33$ & 2 & 4.7 & 0 & 0.0 \\
\hline $18+31$ & 8 & 18.6 & 1 & 100.0 \\
\hline $18+33$ & 4 & 9.3 & 0 & 0.0 \\
\hline $16+18+31$ & 15 & 34.9 & 0 & 0.0 \\
\hline $16+18+33$ & 5 & 11.6 & 0 & 0.0 \\
\hline
\end{tabular}

that the presence of high-risk types of HPV alone is not sufficient to implement the full process of tumourigenesis and that further changes would accumulate over time in a stepwise manner to cause the disease. This possible mechanism suggests a need for further studies with larger cohorts of patients. Adding other investigations and methods to test for E6 and E7 oncogenes and other transforming genes would be mandatory to determine clearly the exact role of those viruses in the genesis of breast lesions $(9,21)$.
The detection of high oncogenic HPV genotypes in patients with breast cancer requires prompt action to control the spread of that sexually transmitted infection among the Iraqi general population.

Competing interests: None declared.

\section{References}

1. GLOBOCAN 2008: cancer incidence and mortality worldwide. Lyon, France: International Agency for Research on Cancer; 2010.

2. Iraqi cancer registry 2008. Baghdad, Iraq: Iraqi Cancer Board, Ministry of Health, 2010.

3. Alwan NA. Breast cancer: demographic characteristics and clinico-pathological presentation of patients in Iraq. East Mediterr Health J. 2010 Nov;16(11):1159-64. PMID:21218740

4. al-Alwan NA. DNA proliferative index as a marker in Iraqi aneuploid mammary carcinoma. East Mediterr Health J. 2000 Sep-Nov;6(5-6):1062-72. PMID:12197329

5. Hsu CR, Lu TM, Chin LW, Yang CC. Possible DNA viral factors of human breast cancer. Cancers (Basel). 2010;2(2):498-512. PMID:24281079

6. Gumus M, Yumuk PF, Salepci T, Aliustaoglu M, Dane F, Ekenel $M$, et al. HPV DNA frequency and subset analysis in human breast cancer patients' normal and tumoral tissue samples. J Exp Clin Cancer Res. 2006 Dec;25(4):515-21. PMID:17310842

7. Kulka J, Kovalszky I, Svastics E, Berta M, Füle T. Lymphoepithelioma-like carcinoma of the breast: not Epstein-Barr virus-, but human papilloma virus-positive. Hum Pathol. 2008 Feb;39(2):298-301. PMID:18206498

8. Lawson JS, Glenn WK, Salmons B, Ye Y, Heng B, Moody P, et al. Mouse mammary tumor virus-like sequences in human breast cancer. Cancer Res. 2010 May 1;70(9):3576-85. PMID:20388779

9. Heng WK, Glenn YY. Tran W et al. Human papilloma viruses is associated with breast cancer. British Journel of Cancer, 2009, 101:1345-1350.

10. Amarante MK, Watanabe MA. The possible involvement of virus in breast cancer. J Cancer Res Clin Oncol. 2009 Mar;135(3):329-37. PMID:19009309

11. Lawson JS, Glenn WK, Heng B, Ye Y, Tran B, Lutze-Mann L, et al. Koilocytes indicate a role for human papilloma virus in breast cancer. Br J Cancer. 2009 Oct 20;101(8):1351-6. PMID:19773762

12. Zlobec I, Steele R, Michel RP, Compton CC, Lugli A, Jass JR. Scoring of p53, VEGF, Bcl-2 and APAF-1 immunohistochemistry and interobserver reliability in colorectal cancer. Mod Pathol. 2006 Sep;19(9):1236-42. PMID:16741523 
13. El-Sisy NA. Immunohistochemical detection of $\mathrm{p} 53$ in ameloblastoma. J Oral Pathol. 1999;5:478-89.

14. Liu Y, Klimberg VS, Andrews NR, Hicks CR, Peng H, ChirivaInternati $M$, et al. Human papillomavirus DNA is present in a subset of unselected breast cancers. J Hum Virol. 2001 NovDec;4(6):329-34. PMID:12082399

15. Kan CY, lacopetta BJ, Lawson JS, Whitaker NJ. Identification of human papillomavirus DNA gene sequences in human breast cancer. Br J Cancer. 2005 Oct 17;93(8):946-8. PMID:16222323

16. Yasmeen A, Bismar TA, Kandouz M, Foulkes WD, Desprez PY, Al Moustafa AE. E6/E7 of HPV type 16 promotes cell invasion and metastasis of human breast cancer cells. Cell Cycle. 2007 Aug 15;6(16):2038-42. PMID:17721085

17. Widschwendter A, Brunhuber T, Wiedemair A, MuellerHolzner E, Marth C. Detection of human papillomavirus DNA in breast cancer of patients with cervical cancer history. J Clin Virol. 2004 Dec;31(4):292-7. PMID:15494272

18. de Villiers EM, Sandstrom RE, zur Hausen H, Buck CE. Presence of papillomavirus sequences in condylomatous lesions of the mamillae and in invasive carcinoma of the breast. Breast Cancer Res. 2005;7(1):R1-11. PMID:15642157

19. Choi YL, Cho EY, Kim JH, Nam SJ, Oh YL, Song SY, et al. Detection of human papillomavirus DNA by DNA chip in breast car- cinomas of Korean women. Tumour Biol. 2007;28(6):327-32. PMID:18391549

20. Lindel K, Forster A, Altermatt HJ, Greiner R, Gruber G. Breast cancer and human papillomavirus (HPV) infection: no evidence of a viral etiology in a group of Swiss women. Breast. 2007 Apr;16(2):172-7. PMID:17088061

21. Khan NA, Castillo A, Koriyama C, Kijima Y, Umekita Y, Ohi $Y$, et al. Human papillomavirus detected in female breast carcinomas in Japan. Br J Cancer. 2008 Aug 5;99(3):408-14. PMID:18648364

22. Rintala MA, Grénman $S E$, Järvenkylä $M E$, Syrjänen KJ, Syrjänen SM. High-risk types of human papillomavirus (HPV) DNA in oral and genital mucosa of infants during their first 3 years of life: experience from the Finnish HPV Family Study. Clin Infect Dis. 2005 Dec 15;41(12):1728-33. PMID:16288396

23. Pike MC, Spicer DV, Dahmoush L, Press MF. Estrogens, progestogens, normal breast cell proliferation, and breast cancer risk. Epidemiol Rev. 1993;15(1):17-35. PMID:8405201

24. Chung SH, Wiedmeyer K, Shai A, Korach KS, Lambert PF. Requirement for estrogen receptor alpha in a mouse model for human papillomavirus-associated cervical cancer. Cancer Res. 2008 Dec 1;68(23):9928-34. PMID:19047174 